\title{
Consequences of prematurity in the establishment of the affective bond between teenage mothers and newborns
}

\author{
Consequências da prematuridade no estabelecimento do vínculo afetivo entre mãe \\ adolescente e recém-nascido
}

\section{Consecuencias de la prematuridad en el establecimiento del vínculo afectivo entre madre adolescente y recién nacido}

Monique Linhares Barroso ${ }^{1}$, Aline Lopes de Pontes $^{2}$, Karla Maria Carneiro Rolim ${ }^{3}$

Objective: to grasp under the maternal perception the consequences of prematurity in the establishment of the affective bond between adolescent mothers/premature babies. Methods: descriptive exploratory study, of qualitative nature, with the participation of ten teenage mothers whose newborn preterm infants had been hospitalized in neonatal care units. Subjects were interviewed and one obtained identification data and used issues related to the affective bond between mothers and children. Results: mothers have different perceptions about their children's suffering and consider prematurity a serious problem that hinders the affective bond between mothers/babies. Conclusion: the nursing team must rethink their practices, seeking opportunities for scientific and emotional growth, aiming to promote the mother's stay in the unit, the establishment of the link between teenage mothers/babies and encouraging mothers to have active participation in the recovery of their children.

Descriptors: Infant, Newborn; Premature; Nursing Care; Parent-Child Relations.

Objetivo: apreender sob percepção materna as consequências da prematuridade no estabelecimento do vínculo afetivo mãe adolescente/bebê prematuro. Métodos: estudo exploratório-descritivo, de natureza qualitativa, com participação de dez mães adolescentes, cujos recém-nascidos prematuros encontravam-se internados em Unidade de Terapia Neonatal. Foi realizada entrevista, obtendo-se dados de identificação e utilizando-se de questões relacionadas ao estabelecimento do vínculo afetivo entre as mães e os filhos. Resultados: as mães apresentaram percepções diferentes acerca do sofrimento dos filhos e consideraram a prematuridade um problema grave que dificulta o estabelecimento do vínculo afetivo mãe/ bebê. Conclusão: a equipe de enfermagem deve repensar suas práxis, buscando oportunidades de crescimento científico e emocional, visando favorecer a permanência da mãe na unidade, o estabelecimento do vínculo mãe adolescente/filho e estimulando as mães a terem participação ativa na recuperação dos filhos.

Descritores: Recém-Nascido; Prematuro; Cuidados de Enfermagem; Relações Pais-Filho.

Objetivo: aprehender bajo la percepción materna las consecuencias de la prematuridad en la relación afectiva madre adolescente/bebé prematuro. Métodos: estudio exploratorio, descriptivo, de enfoque cualitativo, con diez madres adolescentes, cuyos recién nacidos prematuros estaban hospitalizados en Unidad de Cuidados Neonatales. Llevada a cabo entrevistada, obteniéndose datos de identificación y utilizándose cuestiones acerca de la relación afectiva madres e hijos. Resultados: madres presentaron diferentes percepciones sobre el sufrimiento de los hijos y consideraron la prematuridad grave problema que dificulta la relación afectiva madre/bebé. Conclusión: el personal de enfermería debe repensar sus prácticas, en busca de oportunidades para el crecimiento científico y emocional, para promover la estancia de la madre en la unidad, la relación madre adolescente/hijo y alentar a las madres a la participación activa en la recuperación de los hijos. Descriptores: Recién Nacido; Prematuro; Atención de Enfermería; Relaciones Padres-Hijo.

\footnotetext{
${ }^{1}$ Universidade de Fortaleza. Fortaleza, Ceará, Brazil.

${ }^{2}$ Instituto do Rim. Fortaleza, Ceará, Brazil.

${ }^{3}$ Universidade de Fortaleza, Maternidade Escola de Assis Chateaubriand. Fortaleza, CE, Brazil.

Corresponding author: Karla Maria Carneiro Rolim

Rua Silva Paulet, 1854. Aptº304 / Bloco A - Aldeota CEP: 60120.021. Fortaleza, CE, Brazil. E-mail: karlarolim@unifor.br
} 


\section{Introduction}

Teenage pregnancy is a psycho-social risk situation for young people who start an unintended family life. Faced with a newborn child, an adolescent mother faces an early maturing process, and experiences the search for her identity, involving and integrating not only the physical, but also the psychoemotional, intellective, family and social development that happen in the phase she is ${ }^{(1)}$.

Maternity introduces a woman into adulthood through changes in the way she sees and faces the world. Complex phenomena can interfere in this stage of life for an adolescent mother such as complications during pregnancy or childbirth, prematurity and child's hospitalization ${ }^{(2)}$. When a teenage mother sees her child hospitalized, she gets away from her routine as a child, and teenager and becomes the mother of a premature newborn who needs hospital care, expanding this difficult situation.

The separation generated by the son's admission in a neonatal intensive care unit can lead to expressions of sadness, doubt, stress, fragility and uncertainty as to the baby's life and to its completeness. It can still generate guilt and a feeling of responsibility for the child's state, as well as hope and resignation ${ }^{(3)}$. The shock due to the hospitalization of a child can compromise the weakly established bond.

The term "bond" is often used to refer to the establishment and development of the mother/baby relationship. During the construction of the bond, a mother hopes that her son fulfills her desire to be a mother. This is possible by the hypotheses that she weaves about a supposed addressing of a demand of love and recognition. Banal and everyday situations, such as the fact that the mother, at one point, assumes that the child smiles at her or when she assumes that he cries due to cold or colic, demanding care, are not settled when it comes to a child with health injuries ${ }^{(4)}$.

The capacity of establishment of the bond mother/baby is often characterized as an innate potential of both, resistant to events that can intervene in this relationship ${ }^{(4)}$. However, the fact of not being able to get the baby in her arms, holding him and putting him to sleep can be quite frustrating for a teenage mother. Even when it is possible to touch him and caress him inside the incubator, many mothers are afraid of this situation ${ }^{(5)}$.

The separation imposed by the admission of the newborn in an intensive care unit is painful for the adolescent mother and also for the baby. Guilt and anxiety are characteristic feelings of parents who get nervous about the child's survival and normality. Thus, the establishment of bonds and attachment can be hampered by the lack of the mother's opportunity to interact with her child, causing disorders in their future relationship. Given the considerations, one aimed to understand, on the maternal perception, the consequences of hospitalization in a neonatal intensive care unit at the affective bond between teenage mothers/premature babies.

\section{Method}

This is an exploratory-descriptive study of qualitative nature ${ }^{(6)}$, held in a public maternity hospital in Fortaleza, Ceará, Brazil, considered of tertiary level, and a reference for obstetric and neonatal care of high complexity.

Participants were ten mothers whose preterm infants were hospitalized in the neonatal intensive care unit from November 2013 to January 2014. Mothers were invited to participate during a visit to the newborn and the interviews were carried out in a private room connected to the intensive care unit. They were conducted in approximately twenty minutes. At first, a semi-structured interview was conducted, allowing the collection of identification data and issues related to the affective bond with their premature children. The research questions were about feelings experienced in the discovery of prematurity and hospitalization; changes in feelings; difficulties associated with adolescence; participation in the newborn's care. 
In the second moment, one used the free observation to realize forms of affective bond between the adolescent mothers/children, such as exchange of looks, affectionate touch, words of comfort and lullaby gestures. Data were recorded in a field diary. The statements were extracted and described in full according to the convergences found in the answers to questions asked to the adolescent mothers about the establishment of the mother/baby bond and their presence in the recovery process of the children in the neonatal intensive care unit, besides the observations done. The speeches of the participants were submitted to five steps of content analysis, namely: pre-analysis; exploitation of material or coding; treatment of results, inference and interpretation ${ }^{(7)}$. Three categories emerged from this analysis: Maternal feelings about children's hospitalization; Maternal participation in the newborn's care and Difficulties in the establishment of the mother/baby bond.

The study was approved by the Ethics Committee in Research with Human Beings. Mothers were interviewed after signing a free and informed consent form and to guarantee their anonymity they were identified by the letter M (M1... M10).

\section{Results}

The mothers of the study were in the age group from 14 to 18 years old. Regarding their marital status, six were single and four were in a consensual union. Schooling ranged from incomplete to complete elementary school. Regarding their origin, some of them lived in the capital and others in the countryside. Concerning the number of children, only one mother had other children.

The reflective description of the themes extracted from the participants' speeches is shown as follows:

\section{Maternal feelings about their children's hospitalization}

Mothers reported feelings abouthospitalization. I was afraid, very afraid of his death, because I found him so small that I thought he wouldn't make it (M1). I felt very sad, I was mad when I heard, I wanted to give my life for him, but I have faith that he will get well soon (M3). It was indifferent, I can't explain what I felt. I only wanted to go home (M6). I was nervous, I've never had a premature child, I don't know anything about it, I hope he comes out soon, I'll kiss him a lot when we get home (M10).

The feelings of the mothers of preterm newborns shown in the statements were ambiguous, because they expressed sadness, fear, and at the same time show confidence, faith and hope for the baby.

\section{Maternal participation in the newborn's care}

When one asked the young mothers about their participation in the care of premature newborns, they responded that they felt their presence as important together with the interdisciplinary team in the care and treatment of the premature child. Yes, because I go there all the time (M8). Yes, because I spend time with him (M2). No, because I don't like to go there (M6) No, because I don't like to see him full of wires (M10).

About their children's future, the mothers answered: I have faith that my son will grow up to become a good man (M8). I want my daughter to grow, study, and to be someone in life (M7). I want him to be an honest and hardworking citizen (M5). I just want him to study very much (M6).

\section{Difficulties in the establishment of the mother/ baby bond}

Regarding the difficulties found and experienced by adolescent mothers to accept a premature infant and to realize the establishment of 
the mother/infant bond, the participants expressed: None, because I already have two children (M2). Yes, because I don't know how to breastfeed, I'm afraid that he might choke (M7). Yes, because I'm afraid of even touching him, because he is very squishy, sickly (M5). No, because I helped my mother raise my brother (M3). I'm afraid of having affection for him (M10).

Mothers talked about the barriers of communication between nurses and teenage mothers in the neonatal intensive care unit, often caused by work overload, lack of time and exclusion of the family in the care process: Girls here at the intensive care unit are really cool, whenever we want, we can get in (M3). Nurses don't give me attention (M6). These girls here look like they are forced to work, they seem very tired (M10).

\section{Discussion}

There are peculiarities in the mother/ premature baby relationship, whose origins are unclear, but are usually attributed to the immaturity of the child and their specific difficulties, to the early separation, to the problems of stimulation and to the emotional maternal experience, such as intrusive and controlling behaviors. These behaviors are the result of the influence of maternal stress, because mothers of premature infants were observed as being less sensitive, what is explained by the traumatic experience of preterm birth for the mother, together with the stress of having a child at risk ${ }^{(8)}$.

The teenage mother of a premature baby, therefore, experiences a period of stress from which numerous problems and concerns emerge, including fear due to the moment of fragility and risk to which the child is exposed; uncertainty as to care; anxiety about the illness, treatment and recovery of the baby, among others. This causes changes in daily life, harming the family's experience and dynamics.

Sadness is considered the most obvious feeling, a normal and healthy reaction to any misfortune, being largely caused by a feeling of sorrow, grief or even loss.

Moreover, one refers to the attachment behavior that is developed since intrauterine life, being essential the contact between mother and child in the early stages of postnatal life ${ }^{(9)}$. During the hospitalization process, the team's contribution is crucial to involve them in the reality, promoting comfort and security for them, besides strengthening the emotional bond between family members especially mothers and newborns $^{(10)}$.

The advance of technology has enabled the life and survival of children before considered inviable. In this context, the use of means that can ensure a loving care and the survival of immature organs should walk together, promoting the development and protecting the mental health of this newborn. Therefore, in abnormal situations of birth, babies need specialized therapy to survive, increasing significantly the number of admissions in the intensive care unit ${ }^{(11)}$.

In this environment, health professionals need to be aware of the loving care of the premature baby, seeking a harmonious relationship and promoting the establishment of the mother/infant bond. Then, they know that this bond is protective to the brain's development, prevents psychiatric disorders, neglect and maltreatment.

Early and prolonged hospitalization in premature infants has been recognized as a risk factor for neurological sequelae, developmental delay, as well as ill-family treatment and even abuse $\mathrm{e}^{(4)}$. This may occur during the long period in which the infant remains in an incubator, often away from his mother's love and warmth, not feeling the smell of her skin and milk, but the smell of substances used in procedures, in the washing of the health professionals' hands and in the bed sheets ${ }^{(9)}$.

The advantages of the maternal involvement are widely recognized, being pointed as a considerable gain to the child, reducing the length of stay, in the baby's behavioral and cognitive conducts and in the brain's architecture modeling, as well as it is beneficial for the treatment and recovery of hospitalized children. When an adolescent mother and her baby stay together after birth, a series of sensory, hormonal, 
physiological, immunological and behavioral events begins, many of which contribute positively to the bond of the mother/child binomial ${ }^{(5)}$.

It is important to emphasize the communication, because when babies are hospitalized in an intensive care unit and undergo several procedures in order to preserve life, mothers have the right to be informed and guided about the approach to be adopted. With this, they can accept and contribute to the treatment, avoiding interruptions or even the non-compliance of procedures $^{(12)}$.

The news of the need for an infant's hospitalization in a neonatal intensive care unit is often sudden, leading to parents negative feelings such as fear, anxiety, guilt and uncertainty. This unexpected event causes almost always some degree of family breakdown due to conflicting and ambiguous feelings that may culminate in the disruption or difficulty in forming and maintaining the bond between parents and children ${ }^{(5)}$.

Each mother reacts differently to her child's situation and prospects about his future, about hospital discharge or possible sequelae. This reaction is a result of how mothers are informed about the risk which newborn are being exposed to, about the physical aspect of the babies, and about the need for monitoring in the neonatal intensive care unit. While babies fight for their lives, their mothers at the same time try to adapt to the psychological consequences generated by an unexpected situation ${ }^{(5)}$.

Some mothers emphasized that they experienced concern about a still uncertain and fragile future, others did not care about this situation. During this separation, they imagined the worst possible upgrades. The birth of a premature baby is a situation of "psychological crisis" in a family, which starts to face an unpredictable and anxiogenic situation, which generates feelings of powerlessness and stress, especially in a mother ${ }^{(4)}$. A baby's prematurity requires hospitalization in the intensive care unit, a factor that impairs the bond between teenage mother/baby.

Mothers of preterm infants who did not receive adequate social support and experienced stressful events during pregnancy had higher psychological weakness, difficulty in exercising "mothering" and in establishing an adequate standard of interaction with the child ${ }^{(13)}$. Regarding the psychological distance, this often occurs not only due to the physical distance of mother and baby, but sometimes it can work as a form of protection or defense to a mother in order to face the period of stress experienced when her baby struggles to survive during hospitalization.

It could be perceived by the speeches that the painful experience of conceiving a child with a serious health problem, premature or low birth weight, triggers, most of the times, a stress process and psychological crises mothers and in their families. Then there are feelings of guilt, and/or ambivalence towards their children. With this, maternity seems to change depending on the need that arises with the problem of babies at risk.

Some mothers are afraid of holding on to their babies and after they do not survive, causing them suffering, experiencing this way a conflict of approaching versus withdrawal from their babies. However, if a mother does not visit her baby and he dies, it is stressed on her the guilt feeling experienced by the condition of the premature birth of her child(5).

For this "mothering" to arise, teenage mothers should develop certain approaching behaviors, through the bond and interactional events. They should, as they approaches their children, even "different", smile, make facial gestures, hug, cuddle, kiss, hum, contemplate them for a long time. These attitudes are considered evidence of bonds, and necessary, even in undesirable situations. Besides the early care to babies at risk by the multidisciplinary team, the mother/son bond, the parents' voice, the affection and love dedicated to newborns are vital to their treatment and recovery and they can be called healers. Therefore, one should give equal value and encouragement to this relationship ${ }^{(5)}$.

Regarding the terms connection and bond, it is emphasized that the period immediately after 
birth is important for the mother/child link. The link phenomenon is proposed as a sensitive period in the first minutes and hours after birth, when mothers and fathers should have a close contact with their babies, aiming at an ideal future development ${ }^{(4)}$.

The maternal fears are justified by the affected self-esteem, by the environment of the neonatal intensive care unit and by the lack of confidence in the ability to raise their children. The incidence of physical and emotional abuse has been considered higher in babies that, due to prematurity, are separated from their parents for some time after birth ${ }^{(14)}$.

The factors surrounding birth may predispose parents to treat their babies this way due to a subconscious rejection. In this sense, it is very important the provision of a support network for teenage mothers, as it can stimulate them, who are apparently less qualified, to form bond with their babies and to approach them, going frequently to the inpatient unit ${ }^{(9)}$.

The loving and unique feelings of parents for their babies start or increase after they have a quiet, private moment together with them ${ }^{(11)}$ Although the term bond is commonly used to refer to the establishment and development of the relationship of the mother/baby, it is hard to find for it an operational definition $^{(15)}$.

Usually, when referring to the mother/baby bond, one considers only their indicators, generally related to behavioral manifestations around its establishment - the look between the mother and her baby, the caress, the kiss and the touch in order to keep in touch and show affection ${ }^{(16)}$. The love of a mother for her child is not an innate feeling, is not an intrinsic part of what composes a hypothetical "feminine nature": it is a feeling that develops according to socioeconomic variations of history, and it may exist, or not, depending on the time and on the material and psychological conditions in which mothers live ${ }^{(16)}$.

When parents understand that their presence is perceived by their children, they try to stay close to them, recognizing that their participation is necessary both in the children's psycho-affective development and in their social roles as "premature" mothers and fathers. In short, it is essential to keep parents informed about the peculiar characteristics that premature babies have, and enable them to understand the calls and responses babies use to express their needs. This decreases their anxiety about their health situation and enhances their perception about the answers that babies show ${ }^{(13)}$.

The assistance to newborns in the neonatal intensive care unit suffered changes, the traditional assistance model focused on sick babies is giving way to a new model that allows the presence of parents and family members in their care ${ }^{(17)}$. The affection between mother and baby, the establishment of the bond is possible through the touch, one of the most effective tools to stimulate this connection, and it is necessary to be stimulated since the unit, including the health care team.

To accomplish this new practice there are laws and policy guidelines that encourage free access of parents in the units, especially mothers, to visit their children, promoting their continuous presence with the hospitalized baby and, if they wish, providing conditions for their accommodation in the units. However, despite advances in the literature and the advent of children's rights legislation, the situation of premature babies has not changed much. Currently, in most hospitals, the visit of parents/family members to newborn infants is still restricted and controlled by rigid rules, and mothers' insertion in the care of premature babies is still limited.

In the routine of neonatal units, it is common not allowing the mother's presence, justified by the implementation of invasive procedures, medical visit time, small physical space and limited human resources. As for the other family members, the situation is even more difficult, as there are few services that allow the entry of family members other than parents, besides not letting them participate in care $^{(17)}$.

During the first visit, mothers need be 
reassured, because the neonatal intensive care unit environment can seem daunting, causing anxiety and as a consequence, harm the mother/baby interaction $^{(3)}$. The explanations about the unit should be simple, giving the opportunity for the formulation of questions about the environment, and clarifying all their doubts ${ }^{(17)}$. The preparation of mothers to see their babies for the first time is a nurse's responsibility, so before entering the unit, mothers should be prepared as to the general appearance of the child, know about the equipment they are using, and the purpose of each one of them. Nurses should also encourage the skin to skin contact, touch and speaking. The access and the permanence of mothers with babies at high-risk are allowed, which encourages family contact ${ }^{(3)}$.

In the hospitalization process of a newborn in a neonatal unit, nursing must endeavor to establish effective communication with families, so that they feel empowered and encouraged to participate in the assistance to their children in an autonomous way. These actions can help minimize the trauma resulting from the therapeutic process and from the temporary leave, which can be long sometimes ${ }^{(9)}$.

Communication together with technological evolution allows the expansion of nurses' way of take care, especially in the hospital setting. It represents the expansion of looking beyond the baby's biological sick body, to see him also as a bio-psycho-socialspiritual being ${ }^{(18)}$.

As to the nurse/mother relationship, nurses need to guide, teach, support and encourage mothers to deal with babies for the first time. Nurses' orientation/education, showing the mother how to touch, dress and feed the baby can be extremely useful to help them overcome their paralysis of motherhood. In a certain way, nurses assume the role of mothers, for these women, teaching them the basic techniques for their babies' care $^{(4)}$.

The permission that an institution provides for a team to relate with patients is important. When there is a change in the institutional policy, it is possible to develop timely, warm and comforting relationships between nurses and mothers. This type of relationship is significant and should change the institutional structures, so that it can happen.

\section{Final Considerations}

From this study it is considered that teenage mothers demonstrate different perceptions about their children's suffering in the environment of the Neonatal Intensive Care Unit, and they consider prematurity a major problem that hinders the establishment of the affective bond between mother/ baby.

It is also considered that teenage mothers of premature newborns experience a period of stress from which numerous problems and concerns emerge, including fear due to the babies's fragility; insecurity in the delivery of care; anxiety about coping with the disease, children's treatment and recovery.

The study also made it possible to apprehend mitigating factors, such as confidence in the team work, combined with hope and optimism about the babies' recovery. Given the above, it is emphasized that nurses play an essential role in the establishment of the adolescent mother/child bond, understanding its importance and encouraging these mothers to exercise active participation in the recovery of their children.-

\section{Collaborations}

Barroso ML and Pontes AL contributed to the design, collection, analysis, interpretation of data and writing of the article. Rolim KMC contributed to the design, orientation, writing, article review and final approval for publication.

\section{References}

1. Schmidt KT, Mello FT, Rosseto EG, Souza SNH. Avaliação da assistência de enfermagem em unidade neonatal na perspectiva dos pais. Cogitare Enferm. 2010; 15(3):460-6. 
2. Silva BT, Santiago LB, Lamonier JA. Apoio paterno ao aleitamento materno. Rev Paul Pediatr. 2012; 30(1):122-30.

3. Perlin DA, Oliveira SM, Gomes GC. A criança na unidade de terapia intensiva neonatal: impacto da primeira visita da mãe. Rev Gaúcha Enferm. 2011; 32(3):458-64.

4. Ferrari AG, Donelli TMS. Tornar-se mãe e prematuridade: considerações sobre a constituição da maternidade no contexto do nascimento de um bebê com muito baixo peso. Contextos Clín. 2010; 3(2):106-12.

5. Rolim KMC, Cruz EMF, Maia LA. A importância do vinculo mãe/filho na atenção humanizada ao recém-nascido prematuro: percepção materna. Rev Tend Enferm Profis. 2012; 5(1):779-83.

6. Minayo MCS. O desafio do conhecimento. Pesquisa qualitativa em saúde. 12 $2^{\mathrm{a}}$ ed. São Paulo: HucitecAbrasco; 2012.

7. Bardin L. Análise de conteúdo. 5a ed. Lisboa: Edições 70; 2010.

8. Frello AT, Carraro TE. Enfermagem e a relação com as mães de neonatos em Unidade de Terapia Intensiva Neonatal. Rev Bras Enferm. 2012; 65(3):514-21.

9. Neves PN, Ravelli APX, Lemos JRD. Atenção humanizada ao recém-nascido de baixo-peso (método mãe canguru): percepções de puérperas. Rev Gaúcha Enferm. 2010; 31(1):48-54.

10. Rocha RS, Lúcio IML, Lopes MMCO, Lima CRC, Freitas ASF. Promoção do cuidado humanizado à família pela equipe de enfermagem na unidade neonatal. Rev Rene. 2011; 12(3):502-9.
11. Anand KJS, Scalzo FM. Can adverse neonatal experiences alter brain development and subsequent behavior. In: MacCartney K, Phillips D, editors. Blackwell handbook of early childhood development. Malden, MA: Wiley, Blackwell; 2011. p. 69-82.

12. Araújo IRB, Oliveira LLS, Santos TMMG, Moraes SDS. Nursing care of the newborns with neonatal jaundice: an integrative review. Rev Enferm UFPI. 2014; 3(1):120-4.

13. Ferreira FR, Callado LM. O afeto do toque: benefícios nos recém-nascidos. Rev Med Saúde Brasília. 2013; 2(2):112-9.

14. Santos JJC, Freitas PM. Planejamento familiar na perspectiva do desenvolvimento. Ciênc Saúde Coletiva. 2011; 16(3):1813-20.

15. Rosa R, Martins FE, Gasperi BL, Monticelli M, Siebert ERC, Martins NM. Mãe e filho: os primeiros laços de aproximação. Esc Anna Nery. 2010; 14(1):105-12.

16. Beltrami L, Moraes AB, Souza APR. Ansiedade materna puerperal e risco para o desenvolvimento infantil. Distúrb Comum. 2013; 25(2):229-39.

17. Costa R, Padilha M, Monticelli M. Production of knowledge about the care given to newborns in neonatal IC: contribution of brazilian nursing. Rev Esc Enferm USP. 2010; 44(1):199-204.

18. Farias LM, Cardoso MVLML, Oliveira MMC, Melo GM, Almeida LS. Comunicação proxêmica entre a equipe de enfermagem e o recém-nascido na unidade neonatal. Rev Rene. 2010; 11(2):37-43. 